\title{
Heavy Metal Accumulation in Fishes of Different Ecological Groups from Kairiai Landfill Regional Aquatic Ecosystem
}

\author{
Gintaras Svecevičius, Nijolè Kazlauskienè, Vytautas Kesminas, Robertas Staponkus, \\ Egidijus Taujanskis, Gintare Sauliutè \\ Institute of Ecology, Nature Research Centre, Akademijos 2, Vilnius LT-08412, Lithuania
}

\begin{abstract}
The main purpose of this study was to determine heavy metal (HM) accumulation in body tissues (gills, liver and muscle) of different ecological group fishes [bentophagous (gibel carp and roach) and predatory (pike and perch)] from Kairiai landfill regional aquatic ecosystem. Test fish were collected during experimental fishing. Heavy metal analysis was performed in accordance with ISO 11047:2004, and $\mathrm{Hg}$ analysis - according to ISO 16772:2004 standard procedures. The following HMs were found in fish body tissues: $\mathrm{Cr}, \mathrm{Cu}, \mathrm{Ni}, \mathrm{Zn}$ and $\mathrm{Hg}$, while $\mathrm{Pb}$ and $\mathrm{Cd}$ content was below the instrument detection limit. The highest amounts were found of $\mathrm{Zn}$, while the lowest of Ni. Nickel and $\mathrm{Cr}$ concentration in bentophagous and liver and muscle as well as $\mathrm{Zn}$ and $\mathrm{Cu}$ concentration in the gills and liver of predatory fish (in $\mathrm{mg} / \mathrm{kg}$ of raw mass) exceeded Lithuanian hygiene standard [maximum-allowable-amount (MAA)] for human consumption. Correlation (Pearson r) between HM content and their concentration in water and bottom sediments as well as various physico-chemical parameters have been also investigated. Very strong and averagely strong relationship has been established between $\mathrm{Ni}$ content in bentophagous fish liver and $\mathrm{HM}$ concentration in the water and bottom sediments as well as $\mathrm{Cl}^{-}, \mathrm{HCO}_{3}^{-}, \mathrm{Na}^{+}, \mathrm{K}^{+}, \mathrm{NH}_{4}^{+}$; between $\mathrm{Zn}$ content in predatory fish gills and $\mathrm{Cl}, \mathrm{HCO}_{3}{ }^{-}, \mathrm{Na}^{+}, \mathrm{K}^{+}, \mathrm{NH}_{4}^{+}, \mathrm{Mg}^{2+}$; between $\mathrm{Cr}$ content in bentophagous fish liver and $\mathrm{HM}^{-}$ concentration in the water as well as $\mathrm{Cl}, \mathrm{HCO}_{3}{ }^{-}, \mathrm{Na}^{+}, \mathrm{K}^{+}, \mathrm{NH}_{4}^{+}, \mathrm{Mg}^{2+}, \mathrm{CO}_{2}$; between $\mathrm{Cu}$ content in bentophagous gills and $\mathrm{HM}^{-}$ concentration in the bottom sediments, and weak relationship between $\mathrm{Hg}$ content in both bentophagous and predatory fish tissues and HM concentration in the water, bottom sediments as well as other physico-chemical parameters. Summarizing the obtained results it could be concluded that Kairiai landfill still remains a serious source of permanent environmental pollution, although it is already closed.
\end{abstract}

Keywords: Fish; heavy metal pollution; accumulation; landfill leachate.

\begin{tabular}{|ll|}
\hline Nomenclature \\
HM & heavy metal \\
S/S & sampling station \\
RM & raw mass \\
MAA & maximum-allowable-amount \\
\hline
\end{tabular}

\section{Introdction}

Urban waste landfills still remain ones of the most dangerous pollution sources because their leachates are often referred to highly toxic wastewaters of constant composition containing persistent (stable) organic and inorganic (heavy metals) pollutants which are non-biodegradable. These persistent pollutants are the most dangerous as they migrate from one biological system to another and accumulate in aquatic organisms [1].

Heavy metals are widely used in various antropogenic activities, and when entering natural waters becomes persistent pollutants of aquatic ecosystems. Copper, zinc, nickel, chromium, cadmium lead and mercury are listed as priority hazardous substances (pollutants) in many countries because of their toxicity, persistence, and affinity for bioaccumulation $[2,3]$. Heavy metals entering the body of a living organism accumulate in the tissues and join ongoing important protein synthesis reactions, and thus migrate across the entire ecosystem [4]. Fish are unique vertebrate organisms capable to uptake heavy metals by two routes: through water and food (gills and intestinal epithelium absorption processes are taking place here) [5]. Bioaccumulation in different fish species is closely related to the HM uptake rates in the tissues and metabolic

Corresponding author: Gintaras Svecevičius. E-mail address: gintaras.svecevicius@takas.lt

http://dx.doi.org/10.3846/enviro.2014.060

(C) 2014 The Authors. Published by VGTU Press. This is an open-access article distributed under the terms of the Creative Commons Attribution License, which permits unrestricted use, distribution, and reproduction in any medium, provided the original author and source are credited. 
activity. Many field and laboratory studies showed that HM accumulation in fish tissues depends on a series of abiotic and biotic factors and their complexity, for example: fish species, its trophic level, feeding habits, age and size, interspecific differences in sensitivity to various metals, concentrations of pollutants in water and sediment, the type of food, physical and chemical properties of water, the chemical element speciation and metal bioavailability [6-16]. Fish is an important source of animal protein for human body, and HM bioaccumulation in the human food chain must be constantly monitored in order to assess the risk to health. Due to the ability to accumulate a variety of contaminants, fish are excellent indicators of ecosystem assessment of water pollution [11, 17-19]. Most studies of the effects of metals on fish are addressed to a particular metal. Meanwhile, in the natural environment, fish are exposed to different HM mixtures, which are usually more toxic than individual metal as their action is additive or more-than-additive (synergistic). Therefore, the results obtained from exposure to a single metal in laboratory studies are hardly comparable with those from natural conditions. It seems that interaction between different metals are related to their competitive uptake from the environment and to different distribution in fish tissues, which results from that certain metals affect the accumulation of other metals in fish [20].

At present in Lithuania are currently approved and forced maximum allowable amounts (MAA) of heavy metals in fish and fish products recommended for human consumption presented in Lithuanian hygiene standard $\mathrm{HN} 54: 2001: \mathrm{Zn}-40, \mathrm{Cu}$ $-10, \mathrm{Ni}-0.5, \mathrm{Hg}-0.5, \mathrm{Cr}-0.3, \mathrm{~Pb}-0.2$ and $\mathrm{Cd}-0.05 \mathrm{mg} / \mathrm{kg}$ of raw mass, respectively [21].

Although at present a huge amount of the data on HM bioaccumulation in fish from natural water bodies has been compiled interspecific differences still remains investigated insufficiently. Obviously, it depends on the chemical nature of HM, the presence of other HM in the water, fish species-specific ecological, behavioral, biochemical and physiological fish body properties Moreover, evident differences in HM bioaccumulation patterns in different fish species have been observed.

The main objectives of the present study was (1) to investigate priority heavy metal $(\mathrm{Zn}, \mathrm{Cu}, \mathrm{Ni}, \mathrm{Cr}, \mathrm{Pb}, \mathrm{Cd} \mathrm{and} \mathrm{Hg}$ ) accumulation process in body tissues (gills, liver and muscle) of different ecological group fishes [bentophagous (gibel carp and roach) and predatory (pike and perch)] from Kairiai landfill regional aquatic ecosystem, (2) to establish the factors which could influence or affect metal accumulation in different fish tissues using correlation analysis (Pearson $r$ ) between different heavy metals, their concentrations in tissues and various external and internal biotic and abiotic factors and (3) to determine $\mathrm{Zn}$ and $\mathrm{Hg}$ accumulation patterns and compare the amounts of these metals in predatory and bentophagous fish body tissues.

\section{Materials and Methods}

\subsection{Test aquatic ecosystem}

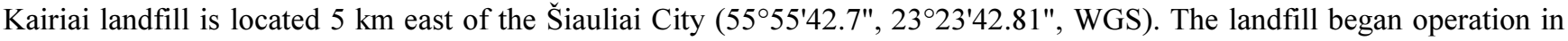
1960 and was closed in 2007. Large-scale household, municipal and industrial waste from various anthropogenic activities containing toxic substances has been deposited in it. The landfill is still continued to seep leachate, which is channeled into two isolated holding reservoirs, and maintained under open-air conditions. It is evident that landfill leachate is penetrating through permeable soils from holding reservoirs and pollute neighboring water bodies. The hydroecosystem incorporated in the landfill area consists of the nameless drainage channel surrounding the landfill which for the 1.5-km falls into the Ginkūnai Pond (of $1.1 \mathrm{~km}^{2}$ area), and in turn the Švedè Creek flows out of the pond.

\subsection{Sampling and water chemistry analysis}

Test fish, water and bottom sediment samples were collected in six sampling stations (S/S) (No. 0, 1, 2, 3, 4, 5) moving away from the leacahte holding reservoirs were set at the distance of about 10, 800, 1300, 2200, 2900 and 3200 meters, respectively in the drainage channel, the pond and the creek along the water flow direction (Fig. 1).

All water samples underwent complete hydrochemical analysis. The following physico-chemical characteristics of water samples were established: dissolved $\mathrm{O}_{2}, \mathrm{pH}$, salinity (\%), conductivity $(\mu \mathrm{S} / \mathrm{cm})$, permanganate number (mg $\left.\mathrm{O} / \mathrm{l}\right)$, equilibrium $\mathrm{CO}_{2}(\mathrm{mg} / \mathrm{l})$, total hardness as $\mathrm{CaCO}_{3}(\mathrm{mg} / \mathrm{l})$, alkalinity as $\mathrm{CaCO}_{3}(\mathrm{mg} / \mathrm{l})$, cations: $\mathrm{Na}^{+}, \mathrm{K}^{+} \mathrm{Ca}^{2+}, \mathrm{Mg}^{2+}, \mathrm{NH}_{4}^{+}$, anions: $\mathrm{Cl}^{-}$, $\mathrm{SO}_{4}{ }^{2}, \mathrm{HCO}_{3}, \mathrm{CO}_{3}{ }^{-}, \mathrm{NO}_{2}{ }^{-}, \mathrm{NO}_{3}{ }^{-}$, as well as total priority heavy metal $(\mathrm{Cu}, \mathrm{Zn}, \mathrm{Ni}, \mathrm{Cr}, \mathrm{Pb}, \mathrm{Cd}, \mathrm{Hg})$ concentrations in the water and bottom sediments were determined according to standardized procedures (ISO: 10304; 9963-1; 14911; 10523; $8467 ; 27888 ; 15586: 2003 ; 1483: 2000)$.

\subsection{Fish, fish tissue and metal analysis}

After the experimental fishing was completed, individuals of the same length group and approximately of the same age have been selected. Predatory fish (pike and perch) and benthophagous fish (gibel carp and roach) has been merged into two main ecologically different groups (bentophagous and predators). The following body tissues have been taken for the analysis:

- Gills (whole organ);

- Liver (whole organ);

- Muscle without skin $(\sim 3 \mathrm{~g})$.

In total from 6 to 9 individuals of mentioned-above groups have been used for every sample station. It should be mentioned that every fish selected for accumulation testing underwent the complete ichthyological analysis procedure (total 
length, standard length, total weight, weight without internal organs, gill and liver somatic indexes, and condition factors according to Fulton and Clark [22, 23]).

The samples were dried in a hot air oven at $85^{\circ} \mathrm{C}$ for 24 hours and heavy metal analysis was performed by atomic absorption spectrophotometry using graphite furnace technique (ISO 11047:2004). Mercury analysis was performed according to ISO 16772:2004 the final concentration being expressed as $\mathrm{mg} / \mathrm{kg}$ of raw mass (RM).

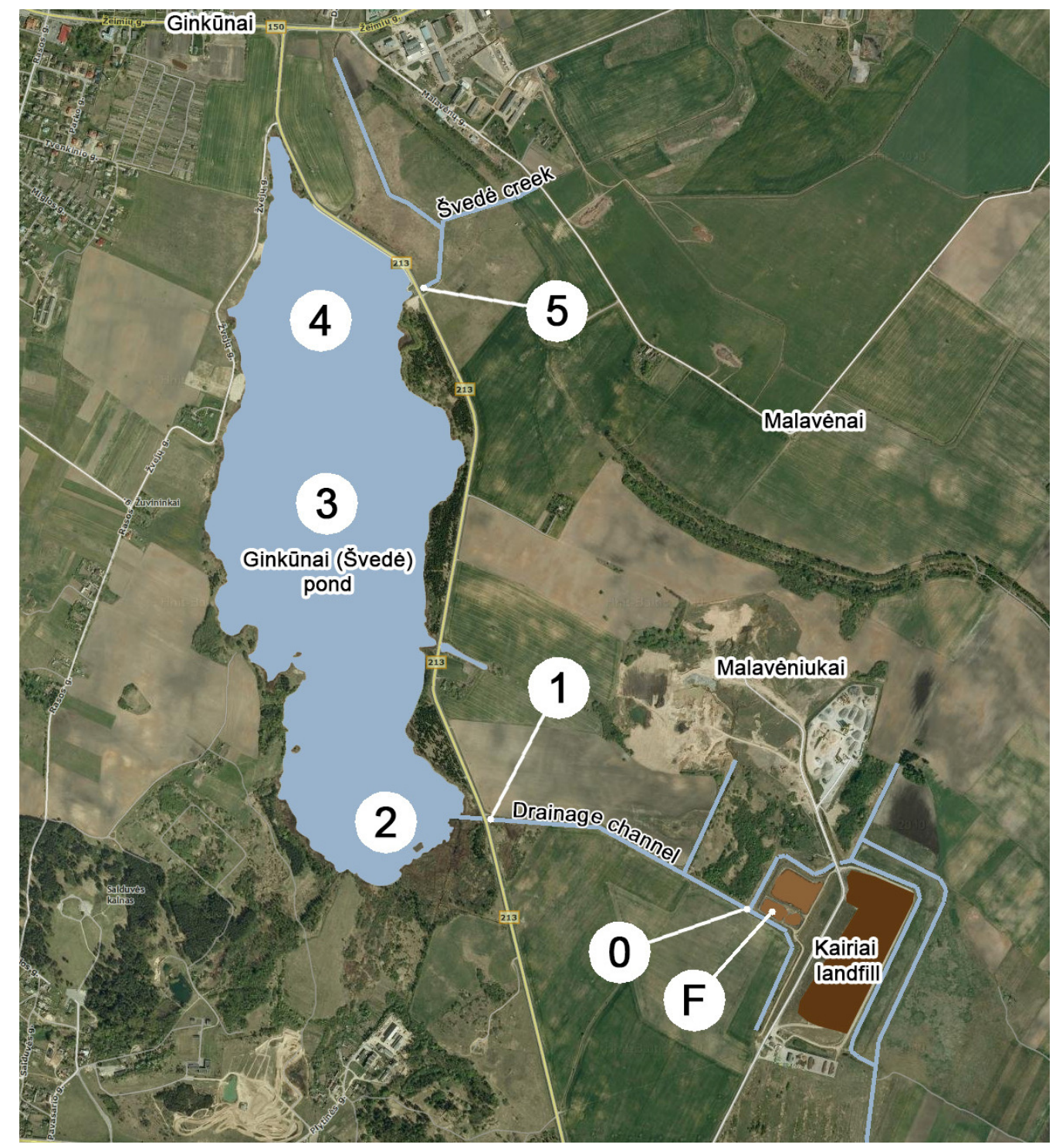

Fig. 1. The scheme of the study area and sampling stations (S/S): landfill leachate reservoir (F), drainage channel (station No. 0 and 1), Ginkūnai pond (station No. 2, 3, and 4) and Švede creek flowing out of the pond (station No. 5)

\subsection{Statistics}

It is also very important to determine the factors which could influence or affect metal accumulation in different fish tissues. Therefore, correlation analysis (Pearson $r$ ) between different heavy metals, their concentrations in tissues and various external and internal biotic and abiotic factors has been performed using STATISTICA 6.0 (StatSoft Inc., Tulsa, Oklahoma, USA) software.

\section{Results and Discussion}

\subsection{Heavy metal accumulation}

The following heavy metals have been detected in test fish body tissues: $\mathrm{Cr}, \mathrm{Cu}, \mathrm{Ni}, \mathrm{Zn}$ and $\mathrm{Hg}$. Lead and $\mathrm{Cd}$ content in the samples were below instrument detection limit. Quantitatively, maximum levels in fish body tissues found were of $\mathrm{Zn}$ while the minimum of $\mathrm{Ni}$ (Table 1). 
Table 1. Heavy metal accumulation [raw mass (RM) in $\mathrm{mg} / \mathrm{kg}$, respectively] in body tissues of bentophagous (gibel carp and roach) and predatory (pike and perch) fishes from Kairiai landfill regional aquatic ecosystem (Mean $\pm \mathrm{SD}$ )

\begin{tabular}{|c|c|c|c|c|c|c|c|}
\hline \multirow{2}{*}{$\begin{array}{c}\text { Sampling } \\
\text { Station } \\
(\mathrm{S} / \mathrm{S})\end{array}$} & \multirow{2}{*}{$\begin{array}{c}\text { Fish ecological } \\
\text { type }\end{array}$} & \multirow{2}{*}{$\begin{array}{l}\text { Body } \\
\text { tissue }\end{array}$} & \multicolumn{5}{|c|}{ Heavy metal } \\
\hline & & & $\mathrm{Cr}$ & $\mathrm{Cu}$ & $\mathrm{Ni}$ & $\mathrm{Zn}$ & $\mathrm{Hg}$ \\
\hline 0 & Bentophagous & $\begin{array}{l}\mathrm{G} \\
\mathrm{L} \\
\mathrm{M}\end{array}$ & $\begin{array}{l}1.0 \pm 0.0^{*} \\
2.0 \pm 0.0^{*} \\
1.5 \pm 0.0^{*}\end{array}$ & $\begin{array}{c}1.6 \pm 0.0 \\
17.8 \pm 0.0^{*} \\
0.0 \pm 0.0\end{array}$ & $\begin{array}{c}0.0 \pm 0.0 \\
1.6 \pm 0.0^{*} \\
1.2 \pm 0.0^{*}\end{array}$ & $\begin{array}{c}49.2 \pm 0.0^{*} \\
32.1 \pm 0.0 \\
8.5 \pm 0.0\end{array}$ & $\begin{array}{l}0.02 \pm 0.00 \\
0.04 \pm 0.00 \\
0.07 \pm 0.00\end{array}$ \\
\hline & Predatory & $\begin{array}{l}\mathrm{G} \\
\mathrm{L} \\
\mathrm{M}\end{array}$ & $\begin{array}{c}1.8 \pm 0.0^{*} \\
0.0 \pm 0.0 \\
0.0 \pm 0.0\end{array}$ & $\begin{array}{l}0.0 \pm 0.0 \\
7.7 \pm 0.0 \\
0.0 \pm 0.0\end{array}$ & $\begin{array}{l}0.0 \pm 0.0 \\
0.0 \pm 0.0 \\
0.0 \pm 0.0\end{array}$ & $\begin{array}{c}78.4 \pm 0.0 * \\
29.9 \pm 0.0 \\
5.1 \pm 0.0\end{array}$ & $\begin{array}{l}0.06 \pm 0.00 \\
0.05 \pm 0.00 \\
0.13 \pm 0.00\end{array}$ \\
\hline 1 & Bentophagous & $\begin{array}{l}\mathrm{G} \\
\mathrm{L} \\
\mathrm{M}\end{array}$ & $\begin{array}{l}0.0 \pm 0.0 \\
0.0 \pm 0.0 \\
0.0 \pm 0.0\end{array}$ & $\begin{array}{l}1.2 \pm 0.0 \\
4.4 \pm 0.0 \\
0.0 \pm 0.0\end{array}$ & $\begin{array}{l}0.0 \pm 0.0 \\
0.0 \pm 0.0 \\
0.0 \pm 0.0\end{array}$ & $\begin{array}{c}90.5 \pm 0.0^{*} \\
50.0 \pm 0.0^{*} \\
10.9 \pm 0.0\end{array}$ & $\begin{array}{l}0.06 \pm 0.00 \\
0.04 \pm 0.00 \\
0.14 \pm 0.00\end{array}$ \\
\hline & Predatory & $\begin{array}{l}\mathrm{G} \\
\mathrm{L} \\
\mathrm{M}\end{array}$ & $\begin{array}{l}0.0 \pm 0.0 \\
0.0 \pm 0.0 \\
0.0 \pm 0.0\end{array}$ & $\begin{array}{l}0.0 \pm 0.0 \\
1.9 \pm 0.0 \\
0.0 \pm 0.0\end{array}$ & $\begin{array}{l}0.0 \pm 0.0 \\
0.0 \pm 0.0 \\
0.0 \pm 0.0\end{array}$ & $\begin{array}{c}14.8 \pm 0.0 \\
20.7 \pm 0.0 \\
7.6 \pm 0.0\end{array}$ & $\begin{array}{l}0.05 \pm 0.00 \\
0.03 \pm 0.00 \\
0.09 \pm 0.00\end{array}$ \\
\hline 2 & Bentophagous & $\begin{array}{l}\mathrm{G} \\
\mathrm{L} \\
\mathrm{M}\end{array}$ & $\begin{array}{l}0.0 \pm 0.0 \\
0.0 \pm 0.0 \\
0.9 \pm 1.5\end{array}$ & $\begin{array}{c}0.0 \pm 0.0 \\
10.8 \pm 3.2 * \\
0.0 \pm 0.0\end{array}$ & $\begin{array}{c}0.0 \pm 0.0 \\
0.0 \pm 0.0 \\
0.6 \pm 1.0^{*}\end{array}$ & $\begin{array}{c}79.0 \pm 7.7 * \\
20.4 \pm 13.6 \\
7.1 \pm 2.2\end{array}$ & $\begin{array}{l}0.04 \pm 0.00 \\
0.04 \pm 0.01 \\
0.15 \pm 0.03\end{array}$ \\
\hline & Predatory & $\begin{array}{l}\mathrm{G} \\
\mathrm{L} \\
\mathrm{M}\end{array}$ & $\begin{array}{l}0.0 \pm 0.0 \\
0.0 \pm 0.0 \\
0.0 \pm 0.0\end{array}$ & $\begin{array}{l}0.0 \pm 0.0 \\
3.0 \pm 2.0 \\
0.0 \pm 0.0\end{array}$ & $\begin{array}{l}0.0 \pm 0.0 \\
0.0 \pm 0.0 \\
0.0 \pm 0.0\end{array}$ & $\begin{array}{c}15.5 \pm 4.5 \\
18.4 \pm 0.8 \\
4.6 \pm 4.7\end{array}$ & $\begin{array}{l}0.06 \pm 0.00 \\
0.09 \pm 0.08 \\
0.23 \pm 0.16\end{array}$ \\
\hline 3 & Bentophagous & $\begin{array}{l}\mathrm{G} \\
\mathrm{L} \\
\mathrm{M}\end{array}$ & $\begin{array}{c}0.5 \pm 0.8^{*} \\
0.2 \pm 0.3 \\
0.3 \pm 0.4\end{array}$ & $\begin{array}{c}0.4 \pm 0.6 \\
10.9 \pm 3.2 * \\
0.0 \pm 0.0\end{array}$ & $\begin{array}{l}0.0 \pm 0.0 \\
0.0 \pm 0.0 \\
0.0 \pm 0.0\end{array}$ & $\begin{array}{c}62.5 \pm 18.5 * \\
19.3 \pm 2.5 \\
3.8 \pm 3.5\end{array}$ & $\begin{array}{l}0.03 \pm 0.01 \\
0.03 \pm 0.01 \\
0.16 \pm 0.01\end{array}$ \\
\hline & Predatory & $\begin{array}{l}\mathrm{G} \\
\mathrm{L} \\
\mathrm{M}\end{array}$ & $\begin{array}{l}0.0 \pm 0.0 \\
0.0 \pm 0.0 \\
0.0 \pm 0.0\end{array}$ & $\begin{array}{l}0.0 \pm 0.0 \\
3.9 \pm 0.5 \\
0.0 \pm 0.0\end{array}$ & $\begin{array}{l}0.0 \pm 0.0 \\
0.0 \pm 0.0 \\
0.0 \pm 0.0\end{array}$ & $\begin{array}{c}13.1 \pm 1.9 \\
18.6 \pm 4.5 \\
4.7 \pm 0.6\end{array}$ & $\begin{array}{l}0.10 \pm 0.04 \\
0.27 \pm 0.08 \\
0.44 \pm 0.19\end{array}$ \\
\hline 4 & Bentophagous & $\begin{array}{l}\mathrm{G} \\
\mathrm{L} \\
\mathrm{M}\end{array}$ & $\begin{array}{l}0.0 \pm 0.0 \\
0.0 \pm 0.0 \\
0.0 \pm 0.0\end{array}$ & $\begin{array}{c}0.9 \pm 0.8 \\
10.7 \pm 5.2 * \\
0.0 \pm 0.0\end{array}$ & $\begin{array}{l}0.0 \pm 0.0 \\
0.0 \pm 0.0 \\
0.0 \pm 0.0\end{array}$ & $\begin{array}{c}84.0 \pm 20.0 * \\
16.3 \pm 1.3 \\
0.0 \pm 0.0\end{array}$ & $\begin{array}{l}0.03 \pm 0.01 \\
0.02 \pm 0.01 \\
0.10 \pm 0.04\end{array}$ \\
\hline & Predatory & $\begin{array}{l}\mathrm{G} \\
\mathrm{L} \\
\mathrm{M}\end{array}$ & $\begin{array}{l}0.0 \pm 0.0 \\
0.0 \pm 0.0 \\
0.0 \pm 0.0\end{array}$ & $\begin{array}{l}0.0 \pm 0.0 \\
3.3 \pm 0.5 \\
0.0 \pm 0.0\end{array}$ & $\begin{array}{l}0.0 \pm 0.0 \\
0.0 \pm 0.0 \\
0.0 \pm 0.0\end{array}$ & $\begin{array}{c}13.2 \pm 1.3 \\
17.5 \pm 2.7 \\
2.5 \pm 2.2\end{array}$ & $\begin{array}{l}0.08 \pm 0.02 \\
0.30 \pm 0.17 \\
0.50 \pm 0.16\end{array}$ \\
\hline 5 & Bentophagous & $\begin{array}{l}\mathrm{G} \\
\mathrm{L} \\
\mathrm{M}\end{array}$ & $\begin{array}{c}0.0 \pm 0.0 \\
3.0 \pm 0.0^{*} \\
0.0 \pm 0.0\end{array}$ & $\begin{array}{l}1.0 \pm 0.0 \\
4.4 \pm 0.0 \\
0.0 \pm 0.0\end{array}$ & $\begin{array}{c}0.0 \pm 0.0 \\
2.0 \pm 0.0^{*} \\
0.0 \pm 0.0\end{array}$ & $\begin{array}{c}65.7 \pm 0.0 * \\
46.0 \pm 0.0 * \\
7.9 \pm 0.0\end{array}$ & $\begin{array}{l}0.04 \pm 0.00 \\
0.07 \pm 0.00 \\
0.09 \pm 0.00\end{array}$ \\
\hline & Predatory & $\begin{array}{l}\mathrm{G} \\
\mathrm{L} \\
\mathrm{M}\end{array}$ & $\begin{array}{c}0.4 \pm 0.6^{*} \\
0.0 \pm 0.0 \\
0.4 \pm 0.6^{*}\end{array}$ & $\begin{array}{c}0.7 \pm 0.9 \\
11.3 \pm 12.5^{*} \\
0.0 \pm 0.0\end{array}$ & $\begin{array}{l}0.0 \pm 0.0 \\
0.0 \pm 0.0 \\
0.0 \pm 0.0\end{array}$ & $\begin{array}{c}44.2 \pm 44^{*} \\
26.5 \pm 22.2 \\
0.0 \pm 0.0\end{array}$ & $\begin{array}{l}0.05 \pm 0.02 \\
0.04 \pm 0.01 \\
0.09 \pm 0.03\end{array}$ \\
\hline
\end{tabular}

Note: G (gills), L (liver), M (muscle). Asterisks (*) denote exceeded metal content (MAA) recommended for human consumption in fish and fish products indicated in Lithuanian hygiene standard $\mathrm{HN} 54: 2001: \mathrm{Zn}-40, \mathrm{Cu}-10, \mathrm{Ni}-0.5, \mathrm{Hg}-0.5, \mathrm{Cr}-0.3, \mathrm{~Pb}-0.2$ and Cd $-0.05 \mathrm{mg} / \mathrm{kg}$ of $\mathrm{RM}$, respectively [21].

Data obtained showed that HM accumulation in fish was metal and tissue specific, i.e. a different tissue showed different capacity for accumulating HMs. In general, all tissues contained high concentrations of $\mathrm{Zn}$ and $\mathrm{Cu}$, but a much lower concentrations of $\mathrm{Cr}$, Ni, and $\mathrm{Hg}$. Such great differences in $\mathrm{HM}$ accumulation could be explained, apparently, by their reliance to different categories of $\mathrm{HM}$ as described by Roy [24]: essential ( $\mathrm{Zn}, \mathrm{Cu})$, non-essential (Ni, $\mathrm{Cr})$, toxic (Cd, $\mathrm{Hg}$ ) heavy metals.

Chromium has been accumulated in the tissues tendentiously and fragmentally. The highest amount of $\mathrm{Cr}$ has been found in all tissues of bentophagous fish (gills, liver and muscle) from S/S No 0 and ranged from 1.0 to $2.0 \mathrm{mg} / \mathrm{kg}$ of RM. Moderate amounts of $\mathrm{Cr}(0.5$ and $0.9 \mathrm{mg} / \mathrm{kg}$ of $\mathrm{RM})$ were also found in the gills and muscle of bentophagous fish from $\mathrm{S} / \mathrm{S}$ No 2 and 3. The highest amount of $\mathrm{Cr}(3.0 \mathrm{mg} / \mathrm{kg}$ of $\mathrm{RM})$ has been established in the liver of bentophagous fish from $\mathrm{S} / \mathrm{S}$ No 5. Whereas, also the highest content of $\mathrm{Cr}(1.8 \mathrm{mg} / \mathrm{kg}$ of $\mathrm{RM})$ has been detected in the gills of predatory fish from $\mathrm{S} / \mathrm{S}$ No 0 , and much smaller $(0.4 \mathrm{mg} / \mathrm{kg}$ of $\mathrm{RM})$ in the gills and muscle of predatory fish from $\mathrm{S} / \mathrm{S}$ No 5 . In all cases $\mathrm{Cr}$ concentration exceeded MAA $(0.3 \mathrm{mg} \mathrm{Cr} / \mathrm{kg}$ of $\mathrm{RM})$ in fish and fish products.

Nickel has been found only in the liver and muscle of bentophagous fish (1.2 and $1.6 \mathrm{mg} / \mathrm{kg}$ of RM) from $\mathrm{S} / \mathrm{S}$ No 1 as well as in the muscle $(0.6 \mathrm{mg} / \mathrm{kg}$ of RM) of fish from S/S No 2 and in the liver $(0.5 \mathrm{mg} / \mathrm{kg}$ of RM) of the fish from S/S No 5 . In all cases Ni concentration exceeded MAA $(0.5 \mathrm{mg} \mathrm{Ni} / \mathrm{kg}$ of RM) in fish and fish products.

Copper has been accumulated tendentiously in bentophagous fish as well as in predatory fish tissues. The highest amount of $\mathrm{Cu}$ [averagely $9.8 \pm 1.9$ in bentophagous fish and $5.2 \pm 2.3 \mathrm{mg} / \mathrm{kg}$ of RM, respectively in predatory fish (mean $\pm \mathrm{SD}$ )] has been found in fish liver. Copper accumulates statistically significantly more in the liver of predatory fish than in the liver of bentophagous fish $(p<0.01)$. Only moderate amounts of $\mathrm{Cu}(0.4$ to $1.6 \mathrm{mg} / \mathrm{kg}$ of $\mathrm{RM})$ have been found in fish gills. In many cases the $\mathrm{Cu}$ concentration in the liver exceeded MAA (10 $\mathrm{mg} \mathrm{Cu} / \mathrm{kg}$ of $\mathrm{RM})$ in fish and fish products.

Zinc has been detected absolutely in all fish tissues. The highest amount of $\mathrm{Zn}(84 \mathrm{mg} / \mathrm{kg}$ of RM) has been established in the gills of bentophagous fish from S/S No 4. Average Zn concentration in bentophagous fish gills amounted 71.8 \pm 7.7 , in the liver $30.7 \pm 2.9$ and in the muscle $6.4 \pm 1.0 \mathrm{mg} \mathrm{Zn} / \mathrm{kg}$ of $\mathrm{RM}$, respectively (mean $\pm \mathrm{SD}$ ). Average zinc concentration in 
predatory fish gills amounted $30.0 \pm 10.6$, in the liver $21.3 \pm 5.0$ and in the muscle $4.1 \pm 1.3 \mathrm{mg} \mathrm{Zn} / \mathrm{kg}$ of RM, respectively (mean \pm SD). Zinc has been much more intensively accumulated in body tissues of bentophagous fish in comparison with predatory fish $(p<0.01)$ and in many cases exceeded MAA ( $40 \mathrm{mg} \mathrm{Zn} / \mathrm{kg}$ of RM) in fish and fish products.

Mercury has been detected absolutely in all fish tissues and ranged from 0.02 to $0.5 \mathrm{mg} \mathrm{Hg} / \mathrm{kg}$ of RM. Mercury has been accumulated mostly in fish muscle and at least in the gills. Average $\mathrm{Hg}$ concentration in bentophagous fish gills amounted $0.04 \pm 0.003$, in the liver $0.04 \pm 0.005$ and in the muscle $0.12 \pm 0.01 \mathrm{mg} \mathrm{Hg} / \mathrm{kg}$ of RM, respectively (mean $\pm \mathrm{SD}$ ). In the gills of predatory fish average $\mathrm{Hg}$ concentration amounted $0.07 \pm 0.01$, in the liver $0.13 \pm 0.06$ and in the muscle $0.25 \pm 0.09$ $\mathrm{mg} \mathrm{Hg} / \mathrm{kg}$ of RM, respectively (mean $\pm \mathrm{SD}$ ). Mercury has been much more intensively accumulated in body tissues of predatory fish in comparison with bentophagous fish $(p<0.01)$ and did not exceed MAA $(0.5 \mathrm{mg} \mathrm{Hg} / \mathrm{kg}$ of RM) in fish and fish products.

\subsection{Correlation analysis}

Significant positive relationship between $\mathrm{Cr}$ concentration in bentophagous fish liver and the gill somatic index as well as Fulton's condition factor has been established $(r=0.81$ to 0.92). Also significant negative relationship between $\mathrm{Cr}$ concentration in predatory fish gills and both types of condition factors (Fulton's and Clark's) has been determined $(\mathrm{r}=-0.99)$. Significant positive relationship between total water toxicity and $\mathrm{Cr}$ concentration in bentophagous fish muscle and predatory fish gills as well as $\mathrm{Cr}$ and $\mathrm{Ni}$ concentration in the water and $\mathrm{Cr}$ concentration in predatory fish gills also has been established $(r=0.83$ to 0.87$)$. Chromium concentration in bentophagous fish gills and liver significantly correlated with $\mathrm{Cl}, \mathrm{HCO}_{3}^{-}, \mathrm{Na}^{+}, \mathrm{K}^{+}$and $\mathrm{NH}_{4}{ }^{+}$concentration $(\mathrm{r}=0.84$ to 0.97$)$. Significant positive relationship between $\mathrm{Cr}$ concentration in predatory fish gills and $\mathrm{Cl}, \mathrm{HCO}_{3}, \mathrm{Na}^{+}, \mathrm{K}^{+}, \mathrm{NH}_{4}{ }^{+}$and equilibrium $\mathrm{CO}_{2}$ also has been found $(\mathrm{r}=0.95$ to $0.98)$.

Statistically significant and strong positive relationship between $\mathrm{Cu}$ concentration in predatory fish liver and the liver somatic index has been found $(r=0.92)$. Also moderate and very strong negative relationship between $\mathrm{Cu}$ concentration in bentophagous fish gills and HM concentration in bottom sediments has been established $(r=-0.84$ to -0.91$)$. Copper concentration in bentophagous as well as in predatory fish body tissues significantly weaker correlated with all physicochemical parameters $(\mathrm{r}= \pm 0.65$ to -0.79$)$. Whereas the $\mathrm{Cu}$ concentration in the bentophagous fish liver significantly positively correlated with $\mathrm{HCO}_{3}$ conentartion $(\mathrm{r}=0.82)$.

Statistically significant moderate and strong positive and negative relationship between $\mathrm{Ni}$ concentration in the bentophagous fish liver and HM concentration in bottom sediments has been found ( $r=-0.75$ to 0.95$)$. The very strong positive relationship between total water toxicity $(\mathrm{r}=0.92)$ and average distance from pollution source as well as $\mathrm{Cr}$ and $\mathrm{Ni}$ concentration in the water also has been established $(\mathrm{r}=0.71$ to -0.75$)$. Nickel concentration in bentophagous fish muscle significantly positively correlated with $\mathrm{Cl}^{-}, \mathrm{HCO}_{3}{ }^{-}, \mathrm{Na}^{+}, \mathrm{K}^{+}$and $\mathrm{NH}_{4}{ }^{+}$concentration $(\mathrm{r}=0.88$ to 0.92$)$. The correlation between $\mathrm{Ni}$ and other physico-chemical parameters has been found to be weak. Whereas, the relationship between $\mathrm{Ni}$ concentration in predatory fish body tissues and other abiotic and biotic factors has been found to be non-estimated.

Statistically significant negative and strong relationship between $\mathrm{Zn}$ concentration in the bentophagous fish liver and a number of exclusive ichthyological analysis characteristics has been established $(r=-0.94$ to -0.98$)$. Also strong negative relationship between $\mathrm{Zn}$ concentration in bentophagous fish gills and $\mathrm{Mg}^{2+}$ concentration $(\mathrm{r}=-0.86)$ as well as between $\mathrm{Zn}$ concentration in predatory fish gills and $\mathrm{Cl}, \mathrm{HCO}_{3}, \mathrm{Na}^{+}, \mathrm{K}^{+}$and $\mathrm{NH}_{4}{ }^{+}$concentration also has been established $(\mathrm{r}=0.82$ to 0.89 ).

Statistically significant negative and positive average and strong relationship between $\mathrm{Hg}$ concentration in bentophagous and predatory fish body tissues as well as in a series of exclusive ichthyological analysis parameters has been established $(\mathrm{r}=-0.79$ to 0.83$)$. It should be noted that $\mathrm{Hg}$ concentration in bentophagous and predatory fish body tissues only weakly correlated with HM concentration in the water and bottom sediments. Strong negative and positive correlation has been found between $\mathrm{Hg}$ concentration in bentophagous fish gills and $\mathrm{NO}_{2}{ }^{-}, \mathrm{NO}_{3}{ }^{-}$and $\mathrm{Mg}^{2+}(\mathrm{r}=-0.83$ to 0.86$)$.

\subsection{Zinc and mercury accumulation patterns}

Since $\mathrm{Zn}$ and $\mathrm{Hg}$ were detected absolutely in all fish tissue samples we decided to determine their accumulation patterns and compare the amounts of these metals in predatory and bentophagous fish body tissues.

Table 2. Comparison of average content of zinc and mercury $(\mathrm{mg} / \mathrm{kg}$ of $\mathrm{RM})(\mathrm{mean} \pm \mathrm{SD})$ in body tissues of different ecological type fishes

\begin{tabular}{|l|l|l|l|}
\hline \multirow{2}{*}{$\begin{array}{l}\text { Fish ecological } \\
\text { type }\end{array}$} & $\begin{array}{l}\text { Body } \\
\text { tissue }\end{array}$ & Heavy metal & Hg \\
\cline { 3 - 4 } Bentophagous & $\mathrm{G}$ & $7 \mathrm{Zn}$ & $0.04 \pm 0.003$ \\
& $\mathrm{~L}$ & $30.7 \pm 2.7^{*}$ & $0.04 \pm 0.05$ \\
& $\mathrm{M}$ & $6.4 \pm 1.9^{*}$ & $0.12 \pm 0.01$ \\
\hline & $\mathrm{G}$ & $30.0 \pm 10.6$ & $0.07 \pm 0.01^{*}$ \\
Predatory & $\mathrm{L}$ & $21.3 \pm 5.0$ & $0.13 \pm 0.06^{*}$ \\
& $\mathrm{M}$ & $4.1 \pm 1.3$ & $0.25 \pm 0.09^{*}$ \\
\hline
\end{tabular}

Note: G (gills), L (liver), M (muscle). Asterisks $\left({ }^{*}\right)$ denote significant differences between means $(t$-test, $p<0.05)$. 
The data obtained showed that bentophagous fish accumulate more $\mathrm{Zn}$ than predatory fish, meanwhile in the case with $\mathrm{Hg}$ everything looks quite conversely: bentophagous fish accumulate less $\mathrm{Hg}$ than predatory fish. Moreover, $\mathrm{Zn}$ is accumulated mostly in the gills while $\mathrm{Hg}$ in the muscle. This evidently demonstrates different biochemistry of different HM in biological systems.

\section{Conclusion}

Heavy metals (HMs) accumulate in both bentophagous (gibel carp and roach) and predatory (pike and perch) fish tissues (gills, liver and muscle) from Kairiai landfill regional aquatic ecosystem. The following HM were found in fish body tissues: $\mathrm{Cr}, \mathrm{Cu}, \mathrm{Ni}, \mathrm{Zn}$ and $\mathrm{Hg}$, while $\mathrm{Pb}$ and $\mathrm{Cd}$ content was below the instrumental detection limit. Heavy metal accumulation in fish was metal and tissue specific, i.e. different tissue showed a different capacity for accumulating HMs. In general, all tissues contained high concentrations of $\mathrm{Zn}$ and $\mathrm{Cu}$, but a much lower concentrations of $\mathrm{Cr}$, $\mathrm{Ni}$, and $\mathrm{Hg}$. The highest amounts were found of $\mathrm{Zn}$, while the lowest of $\mathrm{Ni}$. Zinc and $\mathrm{Hg}$ were detected in absolutely all fish tissue samples. Other HMs were accumulated quite fragmentary. In most cases (except Hg) HM concentration in fish tissues exceeded Lithuanian hygiene standard [maximum-allowable-amount (MAA) in $\mathrm{mg} / \mathrm{kg}$ of raw mass in fish and fish products] for human consumption. Correlation analysis (Pearson $r$ ) between different heavy metals, their concentrations in tissues and various external and internal biotic and abiotic factors showed that no constant rule has existed in patterns of HM accumulation. Ones metals accumulation is affected more by physico-chemical parameters of the water, and the other by biological parameters (gill and liver somatic indexes, condition factors according to Fulton and Clark, general water toxicity, etc.) Comparative analysis of $\mathrm{Zn}$ and $\mathrm{Hg}$ accumulation patterns showed that bentophagous fish accumulate more $\mathrm{Zn}$ than predatory fish, meanwhile in the case with $\mathrm{Hg}$ everything looks quite conversely: bentophagous fish accumulate less $\mathrm{Hg}$ than predatory fish. Moreover, $\mathrm{Zn}$ is accumulated mostly in the gills while $\mathrm{Hg}$ in the muscle. This evidently demonstrates different biochemistry of different HMs in biological systems. Summarizing the obtained results it could be concluded that Kairiai landfill (although it is already closed) still remains a serious source of permanent environmental pollution which causes high-level HM accumulation in fish.

\section{Acknowledgements}

This work is funding from Research Council of Lithuania No. MIP-038/2012.

\section{References}

[1] Kalčíková, G.; Zagorc-Končan, J.; Žgajnar Gotvajn, A. 2011. Evaluation of landfill leachate quality with battery of biotests, Acta Environmentalica universitatis comeniana (Bratislava) 19: 145-15.

[2] Directive 2008/105/EC of the European Parliament and of the Council of 49616 December 2008 on environmental quality standards in the field of water 497 policy, amending and subsequently repealing Council Directives 82/176/EEC, 498 83/513/EEC, 84/156/EEC, 84/491/EEC, 86/280/EEC and amending Directive 499 2000/60/EC of the European Parliament and of the Council, Official Journal L 500 348, 24/12/2008 P. $0084-0097$.

[3] US EPA 2009 National recommended water quality criteria. Office of Water, Office of Science and Technology (4304T). Available via internet: http://www.rsc.org/dose/ title of subordinate document. Accessed 25 Sept 2013

[4] Valavanidis, A.; Vlahogianni, T.; Dassenakis, M.; Scoullos, M. 2006. Molecular biomarkers of oxidative stress in aquatic organisms in relation to toxic environmental pollutants, Ecotoxicology and Environmental Safety 64: 178-189. http://dx.doi.org/10.1016/j.ecoenv.2005.03.013

[5] Bury, N. R.; Walker, P. A.; Glover, C. N. 2003. Nutritive metal uptake in teleost fish, The Journal of Experimental Biology $206: 11-23$. http://dx.doi.org/10.1242/jeb.00068

[6] Clearwater, S. J.; Farag, A. M.; Meyer, J. S. 2002. Bioavailability and toxicity of dietborne copper and zinc to fish, Comparative Biochemistry and Physiology. Part C: Toxicological Pharmacology 132: 269-313.

[7] Canli, M.; Atli, G. 2003. The relationships between heavy metal (Cd, Cr, Cu, Fe, Pb, Zn) levels and the size of six Mediterranean fish species. Environmental Pollution 121: 129-136. http://dx.doi.org/10.1016/S0269-7491(02)00194-X

[8] Green, N.W.; Knutzen, J. 2003. Organohalogens and metals in marine fish and mussels and some relationships to biological variables at reference localities in Norway, Marine Pollution Bulletin 46: 362-377. http://dx.doi.org/10.1016/S0025-326X(02)00515-5

[9] Papagiannis, I.; Kagalou, I.; Leonardos Petridis, D.; Kalfakaou, V. 2004. Copper and zinc in four freshwater fish species from Lake Pamvotis (Greece), Environmental International 30: 357-362. http://dx.doi.org/10.1016/j.envint.2003.08.002

[10] Licata, P.; Trombetta, D.; Cristani, M.; Naccari, C.; Martino, D.; Calo, M.; Naccari, F. 2005. Heavy metals in liver and muscle of bluefin tuna (Thunnus thynnus) caght in the straits of Messina (Sicily, Italy), Environmental Monitoring and Assessment 107: 239-248. http://dx.doi.org/10.1007/s10661-005-2382-1

[11] Немова, Н. Н. 2005. Биохимические эффекты накопления ртути у рыбы. М.: Наука. 164.

[12] Jezierska, B.; Witeska, M. 2006. The metal uptake and accumulation in fish living in polluted waters, In: I Twardowska et al. (eds.) Soil and Water Pollution Monitoring, Protection and Remediation. Springer, pp. 3-23. http://dx.doi.org/10.1007/978-1-4020-4728-2_6

[13] Luczynska, J.; Tonska, E. 2006. The effect of fish size on the content of zinc, iron, copper, and manganese in the muscles of perch (Perca fluviatilis L.) and pike (Esox lucius L.), Archives of Polish Fisheries 14: 5-13.

[14] Karthikeyan, S.; Palaniappan, P. L. R. M.; Sabhanayakam, S. 2007. Influence of pH and water hardness upon nickel accumulation in edible fish Cirrhinus mrigala, Journal of Environmental Biology 28: 489-492.

[15] Oymak, S. A.; Karadede-Akin, H.; Dogan, N. 2009. Heavy metal in tissues of Tor grypus from Atatürk Dam Lake, Euphrates River-Turkey, Journal of Biologia 64: 151-155.

[16] Polak-Juszczak, L. 2009. Temporal trends in the bioaccumulation of trace metals in herring, sprat, and cod from the southern Baltic Sea in the 19942003 period, Chemosphere 76: 1334-1339. http://dx.doi.org/10.1016/j.chemosphere.2009.06.030 
[17] Has-Schön, E.; Bogut, I.; Strelec, I. 2006. Heavy metal profile in five fish species included in human diet, domiciled in the end flow of river Neretva (Croatia), Archives of Environmental Contamination and Toxicology 50: 545-551. http://dx.doi.org/10.1007/s00244-005-0047-2

[18] Schmitt, C. J.; Whyte, J. J.; Roberts, A. P.; Annis, M. L.; May, T. W.; Tillitt, D. E. 2007. Biomarkers of metal exposure in fish from lead-zinc mining areas of Southeastern Missouri, USA, Ecotoxicology and Environmental Safety 67(1): 31-47. http://dx.doi.org/10.1016/j.ecoenv.2006.12.011

[19] Klavins, M.; Potapovics, O.; Rodinov, V. 2009. Heavy metals in fish from lakes in Latvia: concentrations and trends of changes, Bulletin of Environmental Contamination and Toxicology 82: 96-100. http://dx.doi.org/10.1007/s00128-008-9510-x

[20] Jezierska, B.; Sarnowski, P. 2002. The effect of mercury, copper and cadmium during single and combined exposure on oxygen consumption of Oncorhynchus mykiss (WAL.) and Cuprinus carpio (L.) larvae. Archives of Polish Fisheries 10: 15-22.

[21] Higienos norma HN 54:2001. Valstybès Žinios, 2002, Nr. 34-1

[22] Nash, R. D. M.; Valencia, A. H.; Geffen, A. J. 2006. The origin of Fulton's condition factor - setting the record straight, Fisheries 31: 236-238.

[23] Clark, F.N. 1928. The weight-length relationship of the California sardine (Sardina caerulea) at San Pedro, Division of Fish and Game, Fish Bulletin, No. $12,59 \mathrm{pp}$.

[24] Roy, S. P. 2010. Overview of heavy metals and aquatic environment with notes on their recovery, Ecoscan: An International Quarterly Journal of Environmental Sciences 4: 235-240. 